Review Article

\title{
AN EMERGING AQUATIC GREEN GOLD FOR FOOD AND MEDICINE: A REVIEW OF ALGAE FROM NORTH EAST INDIA
}

\author{
JINU MEDHI' ${ }^{1}$, MOHAN CHANDRA KALITA² \\ 1,2Department of Biotechnology, Gauhati University, Guwahati, Assam 781014, India \\ Email: profjinumethi@gmail.com \\ Received: 13 Aug 2020, Revised and Accepted: 06 Oct 2020
}

\section{ABSTRACT}

Given that proper nutrition is a growing concern for rising global populations, sustainable sources of nutritional value are in need. The food product or food derived from nutrients is called nutraceuticals which not only rarely supplement food but also make the treatment or prevention of a disorder and or disease. Algae are a diverse community of autotrophic organisms with the capable of fix atmospheric $\mathrm{CO}_{2}$, efficiently use light energy, ability to grow rapidly and compare to vascular plants, and algae produce more biomass per acre. More than two thousand years, algae are used for the treatment of different ailments and also used as a potential source of food. Due to the characteristics of rapid growth and capable of producing diverse nutritional compound, algae are largely used in dietary supplements and nutraceuticals field. Many kinds of algae have been reported several health benefits from improving the immune system to combat cancer and heart disease. With this background, this current review aims to evaluate the health-promoting effect of Chlorella, Haematococcus, Spirulina, Ankistrodesmus, Botryococcus and Scenedesmus in North East India.

Keywords: Algae, Autotrophic, Health benefits, Nutraceuticals, Nutritional components, North East India

(C) 2020 The Authors. Published by Innovare Academic Sciences Pvt Ltd. This is an open access article under the CC BY license (http://creativecommons.org/licenses/by/4.0/) DOI: http://dx.doi.org/10.22159/ijpps.2020v12i12.39739. Journal homepage: https://innovareacademics.in/journals/index.php/ijpps.

\section{INTRODUCTION}

Microalgae are single-celled, microscopic, photosynthetic species occurring in both marine and freshwater environment. Different type of compounds produced by microalgae such as lipids, carbohydrates and protein along with different value compounds such as pigments, omega- 3 fatty acids and triglycerides that could be exploited for their nutritional value. Most of the microalgae are photosynthetic microorganisms; unlike land plants, it does not contain cell organelles. Using water, solar energy and $\mathrm{CO}_{2}$, the microalgae can be cultivated photosynthetically in artificial tanks, raceway ponds, marginal ponds and shallow lagoons. Although, over 300,000 to 800,000 species of microalgae found in the environment, out of which only 30,000 are documented [1]. The orderly systematic study of algae is called phycology [2]. The microalgae produce secondary metabolites, with potential biological functions and novel structure $[3,4]$.

Additionally, it can produce various useful bio-products including antioxidants, polysaccharides, natural dyes, eicosapentaenoic acid (EPA), bioactive and functional pigments, docosahexaenoic acid (DHA), astaxanthin and $\beta$-carotene [5] (fig. 1). Due to increasing consumer awareness on significant health benefits, the desire for nutraceuticals food products has been significantly increased recently [6]. Microalgae can be called as the factory for several biomolecules including beta-1,3-glucan, Polyunsaturated Fatty Acids (PUFAs), nutraceutical and pharmaceutical compounds, phycobiliprotein, chlorophyll, beta-carotene, lutein and astaxanthin [7]

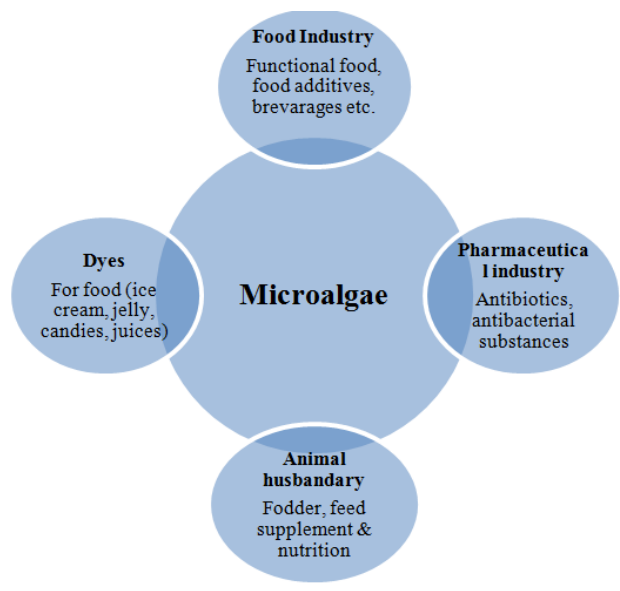

Fig. 1: Application of microalgae in different fields (Hemantkumar and Rahimbhai, [1]

In recent years, a lot of efforts have been devoted to promoting the industrial implementation of microalgae. In this context, the present review provides a brief overview of studies conducted specifically in the northeastern (NE) region, a region with two mega (flora and fauna) biodiversity hotspots of India with abundance. Although there are several review articles, have been published related to 
nutraceuticals value of microalgae, to our knowledge, specific recent reviews of microalgae available in the $\mathrm{NE}$ region is scarce. In addition, reviews in the past had focused only a limited number of algae genus. Therefore, in this review, we attempted to discuss the health-promoting effect of potential strains, the current status of individual species in North East India. In order to identify the studies for this review, several databases were used, including PubMed, Embase, Google Scholar, and specific database such as Science Direct, Springer and Wiley were reviewed. The following keywords were used to extract the data from the identified studies. This includes 'Algae', 'Microalgae', 'Autotrophic', 'Health benefits', 'Nutraceuticals', 'Nutritional components', AND North East India. The paper also focuses on the various application of microalgae, challenges and conclude with the prospects.

\section{Microalgal diversity of Northeast India}

Human health and wellbeing directly reflect the health of biodiversity of that region. Northeast India, with its eight states Sikkim, Tripura, Manipur, Mizoram, Nagaland, Meghalaya, Arunachal Pradesh and Assam, is a part of the world's biodiversity hotspots in both the Himalayas and Indo-Burma. It is a treasure trove of a diversity of faunal and floral which is flourished by varied forms of microalgae, and a member often occupies the lowest level of the food chain of every rivers, ponds, lakes and beels. Northeast India, especially Assam, been mesmerized by the different colures of the water bodies along the roadways because of the various algal blooms around the year [8]. Various studies have documented different microalgae species across the region. For instance, Jena and Adhikary recorded fifty-six taxa of algae belonging to 21 genera for the first time from this region from different water bodies [8].

Interestingly, authors in that study concluded that out of that 16 species were reported first time from north-eastern states of India. Baruah and Kakati [9] documented around 45 species of phytoplankton in the pond dug by the Ahoms, which is $600 \mathrm{y}$ old (fig. 2). Sharma et al. [10] recorded Cyanophyceae sp., Chlorophyceae sp., Bacillariophyceae sp. and Euglenophyceae sp. in four pond ecosystems from Southern Assam. Another study by Ghosh et al., [11] isolated Podohedriella sp. (MC44) from the paddy field, located in Gomati district of Tripura State. This particular species has an efficient to trap carbon from the atmosphere, and therefore mitigate $\mathrm{CO}_{2}$ gas emission from the industries. Further, Muthuraj et al. [12] did show high lipid content in Chlorella p., FC 2 IITG, and therefore, authors in this study demonstrated its potential for biodiesel production.

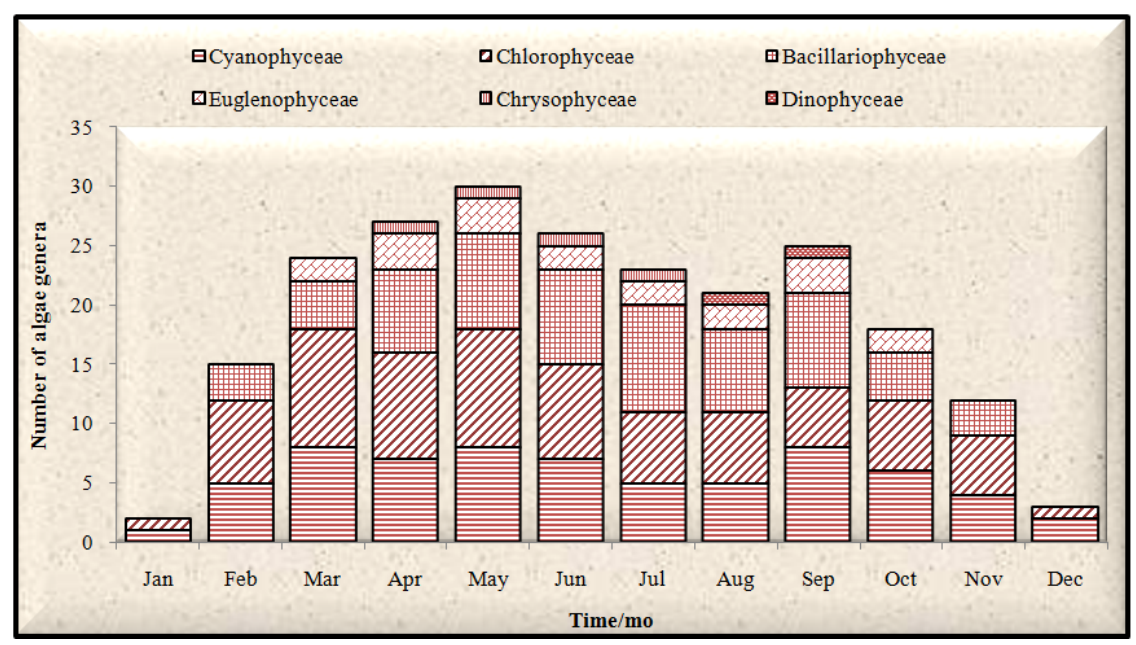

Fig. 2: Monthly occurrences of algal species in Assam [9, 13]

Similarly, around 59 species of microalgae were isolated by Lahan et al. $[15,16]$ from different freshwater bodies in Dhemaji district. The microalgae belong to Xanthophyceae, Bacillariophyceae, Euglenphyceae, Cyanophyceae and Chlorophyceae (fig. 3 and $3 \mathrm{~b}$ ). Authors in this study identified 17 species out of them, and quantified lipid content, as shown in fig. 4. Latest discoveries from algae include two species of Diatom from Sikkim [14]. The 23crore project, Bioresource and Sustainable Livelihood in the Northeast, funded by the Union ministry of science and technology further provides an opportunity to explore further and commercialise endemic bioresources including potential candidate algal strains.

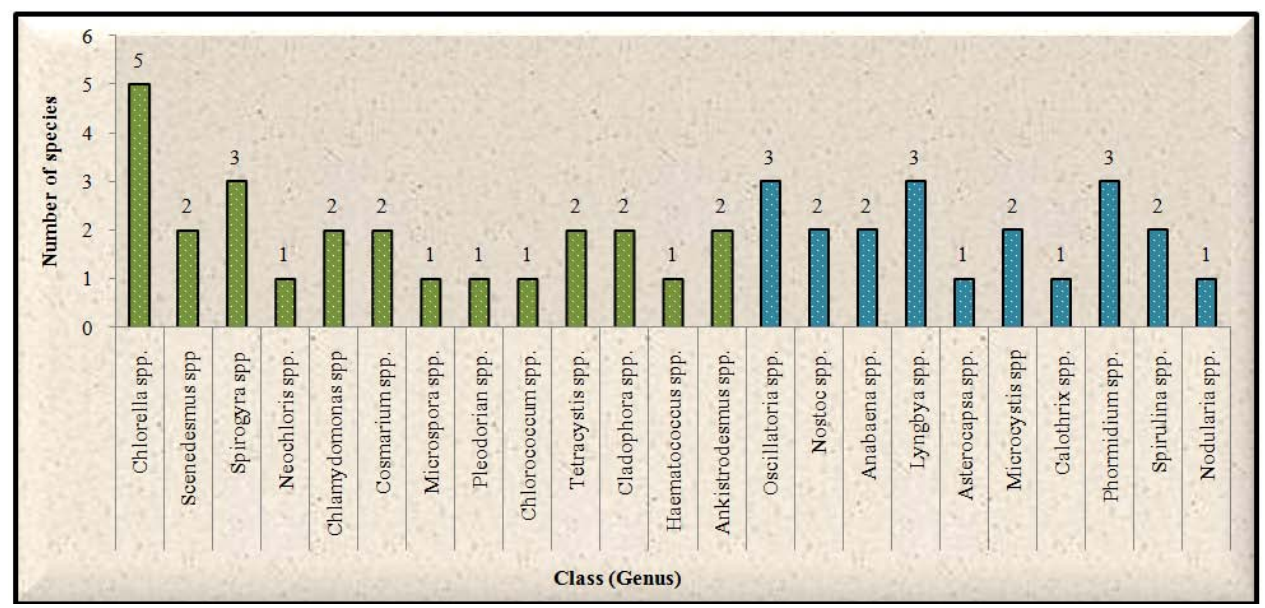

Fig. 3a: Distribution of algal groups isolated $[13,15,16]$ 


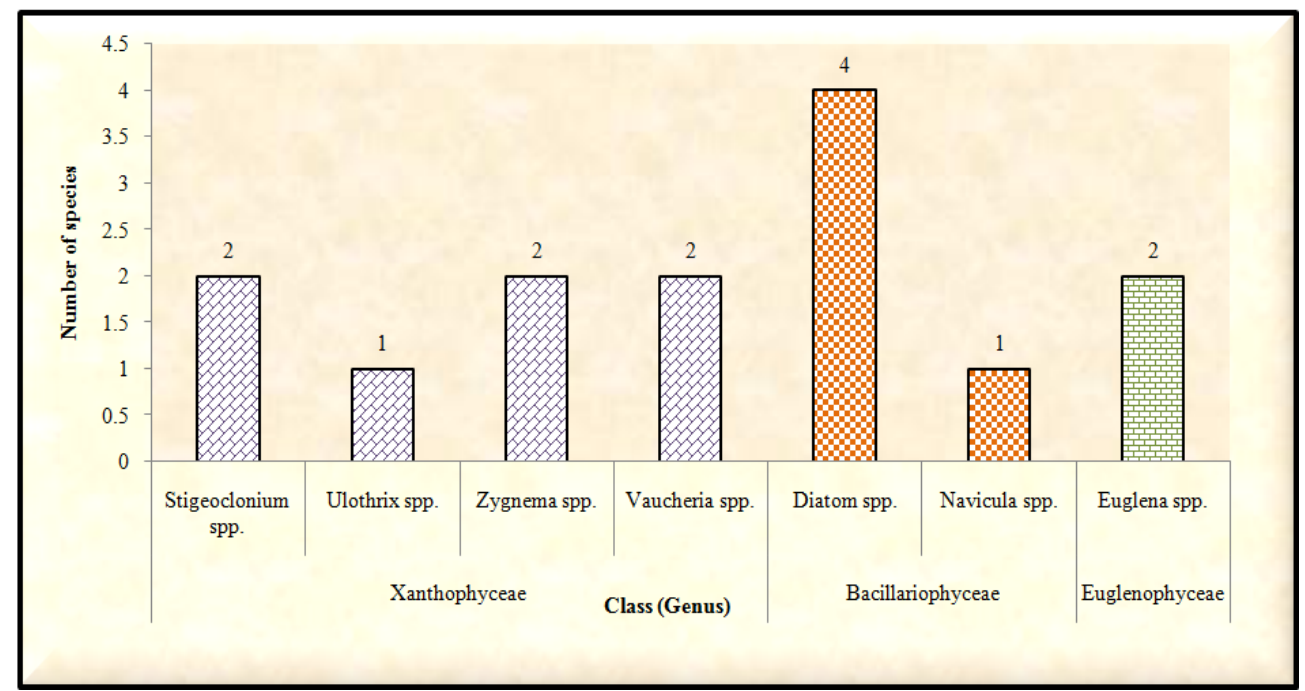

Fig. 3b: Distribution of algal groups isolated $[13,16]$

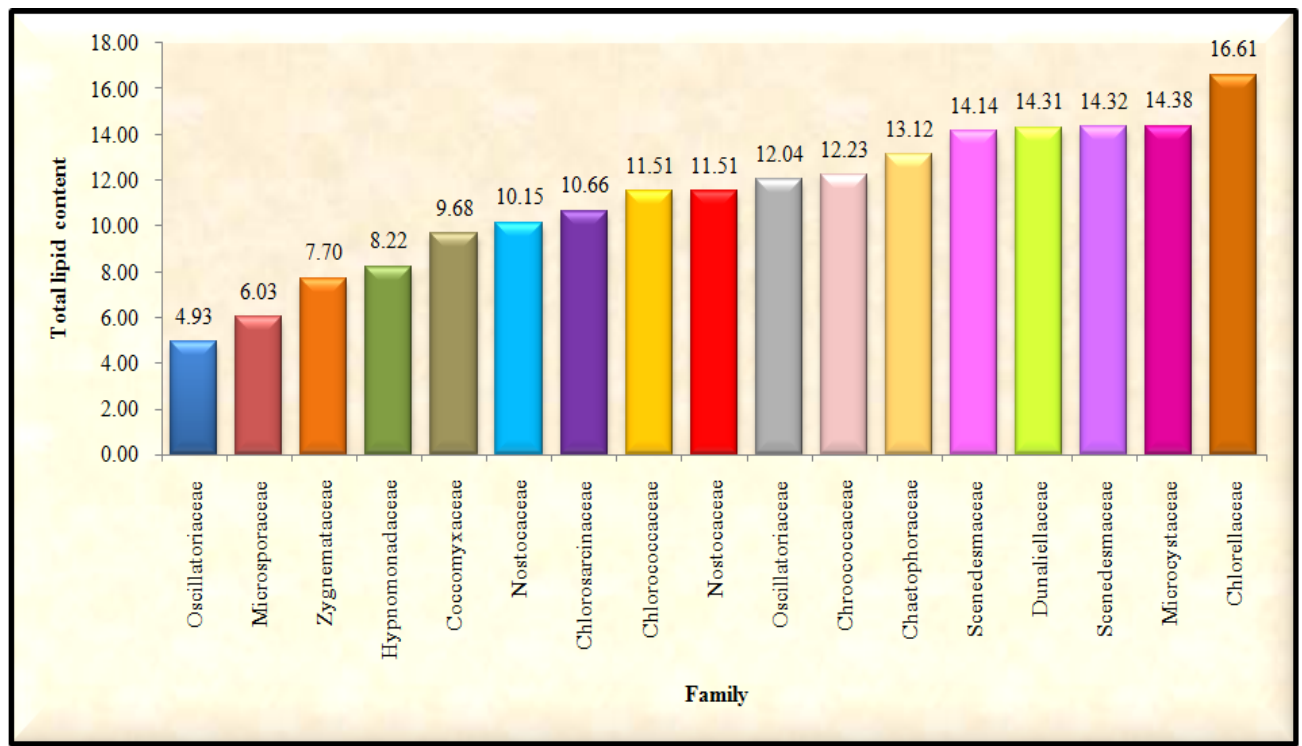

Fig. 4: Total lipid content of the oleaginous algal species isolated from Assam [13]

Thus, overall, several microalgae communities were reported from North East region of India were demonstrated in table 1.

An international organisation reports that approximately 805 million people have been undernourished chronically in 2012-14 by more than 100 million over the past decades and 209 million since 1990-92 according to the latest Food Agricultural Organisation (FA0). But, in the world, about 1 in every 9 individuals still has insufficient food for a healthy and active life that leads to malnutrition. India harbours the largest consumers of antibiotic and among the largest carrier of drug-resistant pathogens [34]. With the growing population, the production of nutritious as well as the necessary quantity of food is an eternal challenge. The United Nations Development Programme (UNDP) sustainable goals to be intended to be met by 2030, including wellbeing, good health, zero hunger and no poverty and clean and affordable energy demands an efficient source of nutrients. In order to meet the demands and to achieve UNDP goals, metabolomics is one of the key tools for nutrition research [35]. The two important deciding features of the so-called nutritional environment are both production and quality. From governments to ordinary individuals, the concern of nutritional environment lies at the centre of everybody's attention. With the increasing world's population, there is also growing concerned to find solutions to feed these populations. To respond, in the last few decades, researchers are turning to non-conventional ways for food sources including "alga culture"-the farming algae for human consumption. For instance, six species of Spirulina have been reported and taxonomically characterised by Brahmaputra valley of Assam, North-East India [36]. Experts suggest the potential of Spirulina to tackle India's malnutrition. However, to develop and market value-added products from microalgae, food industries face several challenges, as shown in fig. 5. To overcome those challenges, and to develop and bring many innovative products and processes into the North East market, several initiatives have been adopted from the government. Recently Council of Scientific and Industrial Research, CSIR-CFTRI, Centre Food Technology Research Institute signed an MoU (Memorandum of Understanding) with Agricultural and Processed Food Products Export Development Authority (APEDA) for opening up a liaison office at Guwahati, Assam India. This agreement will further improve the sector of value addition to food industries including employing microalgae such as Spirulina cultivation. 
Table 1: Microalgae reported from North East region of India

\begin{tabular}{|c|c|c|c|c|c|}
\hline Authors & State(s) & Habitat & $\begin{array}{l}\text { Algae } \\
\text { division/family/genus/species }\end{array}$ & Application(s) & References \\
\hline Jena and Adhikary & $\begin{array}{l}\text { Assam, Nagaland } \\
\text { and Sikkim }\end{array}$ & Pond & Chlorophyta & - & {$[17]$} \\
\hline Devgoswami et al. & Assam & - & $\begin{array}{l}\text { Chlorella, Scenedesmus and } \\
\text { Haematococcus }\end{array}$ & Lipid production & [18] \\
\hline $\begin{array}{l}\text { Goswami and } \\
\text { Kalita }\end{array}$ & Assam & Freshwater & $\begin{array}{l}\text { Scenedesmus quadricauda and } \\
\text { Scenedesmus dimorphus }\end{array}$ & Lipid production & [19] \\
\hline Deka and Sharma & Assam & Fresh water & $\begin{array}{l}\text { Oscillatoria, Lyngbya, } \\
\text { Phormidium, Spirulina, } \\
\text { Hydrocoleum, Microcoleus, } \\
\text { Symploca, Polychlamydum, } \\
\text { Porphyrosiphon and } \\
\text { Katagnymene }\end{array}$ & - & {$[20]$} \\
\hline Gunapati et al. & Manipur & Soil samples & $\begin{array}{l}\text { Anabaenopsis, Wollea, Aulosira, } \\
\text { Nostoc, Anabaena, Scytonema, } \\
\text { Tolypothrix, Microchaete, } \\
\text { Calothrix and Dichothrix }\end{array}$ & - & {$[21]$} \\
\hline Devi and Tiwari & Manipur & $\begin{array}{l}\text { Different } \\
\text { ecological } \\
\text { habitats }\end{array}$ & $\begin{array}{l}\text { Plectonema, Lyngbya, Spirulina, } \\
\text { Oscillatoria, Limnothrix and } \\
\text { Phormidium }\end{array}$ & - & {$[22]$} \\
\hline Singh and Gupta & Manipur & Different rivers & $\begin{array}{l}\text { Lemanea australis, L. torulosa, } L \text {. } \\
\text { fluviatilis, L. mamillosa and } L . \\
\text { catenata }\end{array}$ & - & {$[23]$} \\
\hline Basu et al. & Assam & Freshwater & $\begin{array}{l}\text { Scenedesmus } \\
\text { obliquus (KC733762) }\end{array}$ & $\begin{array}{l}\text { Production of carbohydrate, } \\
\text { protein, lipid, and chlorophyll }\end{array}$ & {$[24]$} \\
\hline Kumar et al. & Assam & Freshwater & Chlorella sorokiniana FC6 IITG & $\begin{array}{l}\text { Biomass and lipid } \\
\text { accumulation }\end{array}$ & {$[25]$} \\
\hline Yasmin et al. & Assam & $\begin{array}{l}\text { Stagnant water } \\
\text { bodies }\end{array}$ & $\begin{array}{l}\text { Chlorophyceae ( } 59 \text { species), } \\
\text { Bacillariophyceae ( } 15 \text { species) } \\
\text { and Cyanophyceae ( } 17 \text { species) }\end{array}$ & - & {$[26]$} \\
\hline Bora et al. & Meghalaya & $\begin{array}{l}\text { Different } \\
\text { ecological } \\
\text { habitats }\end{array}$ & $\begin{array}{l}\text { Anabaena, Nostoc, Calothrix, } \\
\text { Westiellopsis, Gloeocapsa, } \\
\text { Fischerella, Tolypothrix, } \\
\text { Stigonema, Cylindrospermum, } \\
\text { Loriella and Plectonem }\end{array}$ & - & {$[27]$} \\
\hline Thajamanbi et al. & Assam & Rice fields soil & $\begin{array}{l}\text { Nostoc, Calothrix, Anabaena, } \\
\text { Cylindrospermum, Lyngbya, } \\
\text { Oscillatoria and Phormidium }\end{array}$ & - & {$[28]$} \\
\hline \multirow[t]{5}{*}{ Ghosh et al. } & Tripura & Moist soil & Chlorococcum sp. (NITAAP019) & $\begin{array}{l}\text { High lipid, protein, } \\
\text { carbohydrate and biofuel } \\
\text { production }\end{array}$ & [29] \\
\hline & & Paddy field & Korshikoviella sp. (NITAAP017) & $\begin{array}{l}\text { Significant production of lipid, } \\
\text { chlorophyll, carbohydrate and } \\
\text { protein }\end{array}$ & \\
\hline & & Moist soil & Chlorella sp. (NITAAP009) & $\begin{array}{l}\text { Production of carbohydrate, } \\
\text { protein and chlorophyll }\end{array}$ & \\
\hline & & Moist soil & Chlorococcum sp. (NITAAP008) & $\begin{array}{l}\text { High lipid, protein, } \\
\text { carbohydrate and biofuel } \\
\text { production }\end{array}$ & \\
\hline & & Lake & Chlorella sp. (NITAAP011) & $\begin{array}{l}\text { Significant production of } \\
\text { chlorophyll, carbohydrate, } \\
\text { lipid and protein }\end{array}$ & \\
\hline Sehgal et al. & Assam & Fresh water & $\begin{array}{l}\text { Chlorella sorokiniana (NEIST BT- } \\
\text { 2) }\end{array}$ & $\begin{array}{l}\text { High lipid productivity and } \\
\text { biomass yield }\end{array}$ & [30] \\
\hline Das and Deka & Assam & $\begin{array}{l}\text { Oil field } \\
\text { formation water }\end{array}$ & Chlorella vulgaris BS1 & High biomass productivity & {$[31]$} \\
\hline Manchanda et al. & Assam & Water sample & $\begin{array}{l}\text { Botryococcus braunii } \\
\text { (GUBIOTJTBB1) }\end{array}$ & $\begin{array}{l}\text { Hydrocarbon and oil } \\
\text { production }\end{array}$ & {$[32]$} \\
\hline Sarkar et al. & Tripura & - & Chlorella thermophila & $\begin{array}{l}\text { High valued pigments } \\
\text { chlorophyll and carotenoids }\end{array}$ & [33] \\
\hline
\end{tabular}

A glimpse from the ongoing trend in the field of functional foods and supplements revealed bioactive molecules play a major therapeutic role in human disease. Recently with the mushrooming population, a great impact can be seen in the food scenario involving the several products appearance derived from these bioactive molecules. These botanicals, nutraceuticals, and other products influenced the market due to their hybrid nature, somewhere between medicinal drugs and ordinary food. Stephen Defelice coined the term nutraceutical in 1989 by combining the terms nutrition (food or nourishment) and pharmaceuticals (a medical drug). The food product or food derived from nutrients is called nutraceuticals which not only rarely supplement food but also make the treatment or prevention of a disorder and disease. Nutraceuticals have reported health benefits and the treatment of possible fatal illnesses (i.e. cancer, Parkinson's disease, heart disease) [37, 38]. These all algal components gained a lot of attention for having the character to be a candidate for a replace the synthetic components, animal feed and natural supplement for human. With the skyrocketing high-quality nutrients demands, it seems that it 
is the green gold as it will play vital roles in the near future to a food crisis, remedy energy and environment prevailing in the world. Exploring the full potential of algal nutraceuticals is another key step for fulfilling "Aatmanirbhar Bharat Abhiyan" or North-East India. Some important algae, their biologically active compounds are listed in table 2 and for detailed review, refer a paper by Bhattacharjee [39].

Microalgae challenges in food technology

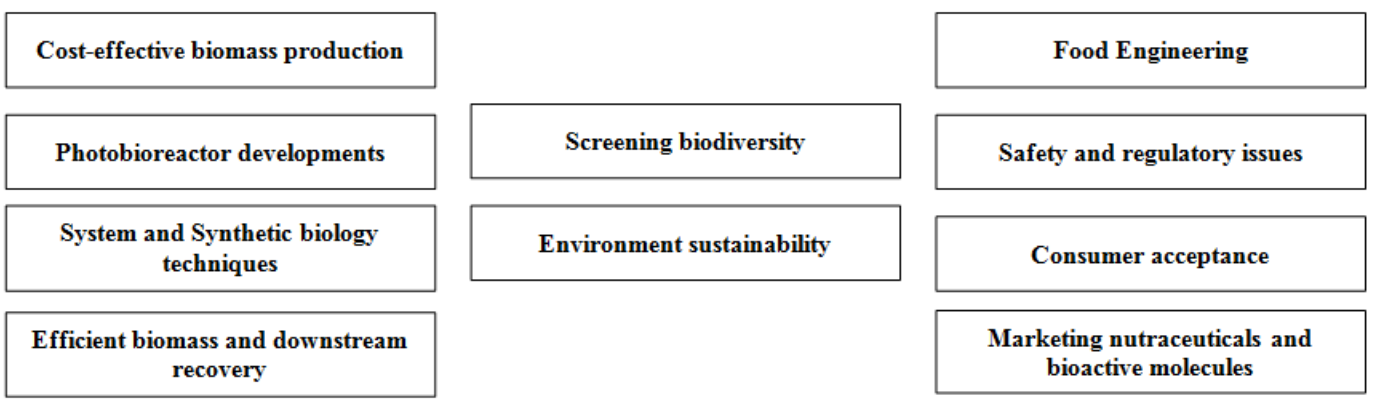

Fig. 5: Microalgae challenges in food technology [13]

Table 2: Bioactive compounds isolated from the various algal genus

\begin{tabular}{lll}
\hline Genus & Bioactive compounds & References \\
\hline Spirulina & Secondary metabolites, photosynthetic pigments, minerals, fatty acids, vitamins, proteins \\
Chlorella & Pigments, polysaccharide, vitamins, peptides, amino acids, proteins, sterols, volatile \\
& compounds, phenolic compounds, Long-Chain Polyunsaturated Fatty Acids \\
Haematococcus & Astaxanthin, lutein, fatty acids & [40] \\
Scenedesmus & Astaxanthin, Vitamins, Lutein, Haemagglutinin, sporopollenin, Mycosporine-like amino acids, \\
& PUFA, MUFA, Chlorophyll a, b, c, & [43] \\
Botryococcus & Carotenoids, fatty acids, hydrocarbons \\
Ankistrodesmus sp. & Phenolic acids and flavonoids \\
\hline
\end{tabular}

\section{Chlorella}

In the Chlorella genus is marketed as a "growth factor" which is an extract of water-soluble extract substances, including $\beta$-glucans, glycoproteins, polysaccharides, minerals, vitamins, amino acids, and nucleic acids [46]. Many useful properties have been indicated by Chlorella sp. extracts, such as antitumor, antioxidant and antibacterial activities and decreasing cholesterol level as well as properties of antioxidant [47-49]. Depending on the extraction conditions, the antioxidant and antibacterial activity varies [50]. Report from the research work with extracts from Chlorella reveals to possess antitumor [47], antioxidant activity in rainbow trout [51], anti-inflammatory [52] and antimicrobial activities [4]. Dried powder of Chlorella sp. as a dietary supplement to stroke-prone spontaneously hypertensive rats (SPSHR) show a beneficial effect on vascular function [53]. Regular supplementation of Chlorella sp. to subjects with mild hypercholesterolemia may act to optimise serum lipid profile TG, apo B, HDL-C/TG, VLDL-C, non-HDL-C and TC [48]. A beneficial immunostimulatory effect can be seen in normal uninfected people by short term supplementation with Chlorella sp. tablets [54]. Different studies also suggest Chlorella sp. supplementation improves the symptoms in fibromyalgia patients $[55,56]$. A major lutein source of Chlorella sp. has been demonstrated to contains properties of anti-cataract and prevent macular degeneration.

It is a unicellular green alga and considered as whole foods because of its richness in protein vitamins and minerals [56]. Its nutrient composition can be listed as chlorophyll 1-4\%, protein 55-67\%, dietary fibre $9-18 \%$ and a large amount of vitamins and minerals [56]. Two isolated Chlorella sp. strains including NITAAP009 and NITAAP011 from Tripura demonstrated chlorophyll 5\%, 5-6.4\%, carbohydrate $22-33 \%, 30-50 \%$, and protein $41-50 \%, 48-60 \%$ respectively [57]. Former strain show higher specific growth rate of $0.125 \mathrm{~d}-1$ than the later one with $0.10 \mathrm{~d}-1$ [57]. The growth profile of Chlorella sp. that was isolated from Assam, investigated in batch mode culture with varying concentration of sodium bicarbonate and
$\mathrm{CO}_{2}$ [18]. Highest growth rate (189.1\% increase in biomass; specific growth=0.704, g/l/day) and content of lipid achieved when supplying $\mathrm{CO}_{2}$ gas (and 1.015 doublings/day, lipid content by weight of dry cells $31 \%$ ). A novel microalgae strain isolated from freshwater samples identified as Chlorella sorokiniana FC6 IITG isolated from North East India was collected [58]. In order to achieve both cell density (biomass) as well as lipid accumulation, different pilot strategies have been formulated. The growth of Chlorella sp. FC2 IITG has been characterized under mixotrophic, heterotrophic and photoautotrophic cultivation conditions [59]. Different strategies for process engineering of Chlorella sorokiniana sp. growth been reported in studies. For instance, under mixotrophic growth of this strain, FC6 IITG led to synchronised growth with high lipid productivity [60]. Cultivation of heterotrophic Chlorella sp. FC2 IITG with novel two-stage continuous was showed for increased productivity of lipid [61]. Thermophilic Chlorella sp. strain was isolated from Tripura processed for the production of high valued pigments chlorophyll and carotenoids using a green solvent like ethanol in less than $6 \mathrm{~min}$ [62]. Among the different culture processes employed for Chlorella sp. cultivation thermophilic Chlorella culture of $30 \mathrm{~L}$ carried out on $50 \mathrm{~L}$ capacity flat-panel photo-bioreactor [62]. Further, to study the growth performance of Chlorella sp. in fluctuating environmental conditions and the presence of contaminants open pond cultivation was employed [59]. The study also shows the Continuous culture regime as a potential tool for Chlorella vulgaris. The microalgae strain collected from Tripura and identified as Chlorella sp. (NITAAP009). The strain had chlorophyll $5 \%$ with a specific growth rate of $0.125 d-1,22-33 \%$ carbohydrate and 41-50\% protein. Similarly another strain isolated from lake area in Tripura and identified as Chlorella sp. (NITAAP011) with large content of chlorophyll (5-6.4\%), low lipids $(1-10 \%)$ with lower specific growth rate $(0.10 \mathrm{~d}-1), 48-60 \%$ protein and 30-50\% carbohydrate [57].

A species of algae were isolated from the oil field formation water in Assam and identified based on the 18S rRNA as Chlorella vulgaris 
BS1. The strain showed high productivity in biomass of $1,76 \mathrm{gm} \mathrm{b} 1$ $\mathrm{d}-1$ (initial inoculum: $1500 \mathrm{mg} \mathrm{L}-1$, specific growth rate: $0.21 \mathrm{~d}-1$ ) [31]. Recently, the strain Chlorella sorokiniana (NEIST BT-2) isolated from freshwater in Assam and showed high lipid productivity $\left(107.60 \pm 10.175 \mathrm{mg} \mathrm{L}^{-1} \mathrm{~d}^{-1}\right)$ and biomass yield $\left(2.09 \pm 0.037 \mathrm{~g} \mathrm{~L}^{-1}\right)$ [30]. The association of prokaryotes, which synthesise vitamin B12 with the surface of the seaweed, promotes this amount of vitamin present in the algae. In microalgae such as Chlorella sp. the vitamin B12 content is stated to be higher, offering $33.3 \mathrm{~g} / \mathrm{kg}$ of fresh weight. The active vitamin B12 coenzymes in Chlorella supplements constituted around 60 per cent of the total vitamin B12 [63].

\section{Haematococcus sp}

It is a green free-floating alga and can accumulate up to 5\% DW (dry weight) of astaxanthin for which it occupies the top position in the list of natural sources of astaxanthin. Astaxanthin has recorded at least ten times stronger antioxidant activity than beta-carotene and 1000 times stronger than vitamin E. It functions effectively in reducing non-esterified fatty acids, plasma triglycerides levels and arterial blood pressure [64].

Astaxanthin possesses various health benefits in humans like pigmentation and reproductive behaviour, immune response, enhanced vision, protection against the effects of UV radiation and protection of polyunsaturated fatty acids against oxidation [65]. The pigment documented to have anti-inflammatory, anti-oxidative, antibacterial, anti-cancer, activities. Natural astaxanthin also found to be effective against dyspepsia caused by Helicobacter pylori [66]. Moreover, this enigmatic pigment also plays a significant role in the neural damage treatment and prevention linked with age-related macular degeneration. Astaxanthin already got the tagline of "A rising star" because of its effective treatment in central nervous system injuries, spinal cord damage, Parkinson's disease, Alzheimer disease [67]. These high-value carotenoids are also striding its beneficiary effect towards the prevailing diabetes problem by preserving the betacell function and reducing the glucose toxicity [68]. Compared to synthetic one natural astaxanthin produced by Haematococcus sp. has significantly greater antioxidant capacity. Mass manufacturing companies of Haematococcus sp. primarily for astaxanthin, include Aquasearch Inc., Alga Technologies, Valensa International, Fuji Health Science, BioReal, Inc., Parry Nutraceuticals, Cynotech Corporation.

Haematococcus sp. with a concentration of 30 ppm of sodium bicarbonate can develop in BG11 media. The best growth of Haematococcus sp. strain was observed in CO2 gas at $4758 \mathrm{mg} / \mathrm{l}(134.1$ $\mathrm{mg} / \mathrm{l}$ for $7 \mathrm{~d}$ ) and $30 \mathrm{ppm}$ bicarbonate $(72.9 \mathrm{mg} / \mathrm{l} /$ day for $17 \mathrm{~d})$ [18]. Various studies report Haematococcus sp. from different regions within Assam. Using the Winogradsky Column, it was among the algal varieties isolated from the Guwahati Panikhaiti area, Assam [69]. Further Haematococcus sp. was reported from Umiew river in Meghalaya [70] and vegetable fields of Cachar district, Assam [71]. The Haematococcus $\mathrm{sp}$. is grown commercially either in controlled photobioreactors or in large-scale outdoor systems. Though this species is reported from different localities within North East India, until now, no reports are present for characterisation of bioactive metabolites from this particular strain. This opens up many avenues for characterization starting from culture parameters optimization to value added chemicals extraction including astaxanthin from this endemic potential strain.

\section{Spirulina}

Spirulina is a prokaryotic cyanobacterium that has been developed commercially for use for more than thirty years, including nutraceuticals, pharmaceuticals, aquaculture, food dyes, food dyes, vitamin supplements and fish food [72-74]. The nutrients compositions that make the Spirulina a superfood are minerals, omega-6 fatty acids, vitamin E, chlorophyll, phycocyanin and Bvitamins [73]. The large amount of natural proteins found in the Spirulina, i.e. 60-70 \%, up to ten times more beta-carotene and five times than of meat than carrot per unit mass. In microalgae Spirulina, the vitamin B12 content found to be higher, offering $15.3 \mathrm{~g} / \mathrm{kg}$ of fresh weight [63]. It is the main vitamin B12 vegetable source and contains two and a half times the liver content.

The nutrient profile of Spirulina vs other foods can be summarized as more anti-inflammatory and antioxidant activity in $3 \mathrm{~g}$ of Spirulina than in five servings of vegetables and fruits, $5100 \%$ more iron than spinach, compared to carrots, $3100 \%$ more beta carotene, $670 \%$ more protein than tofu and $180 \%$ more calcium than whole milk [75]. Incredible benefits have been reported in the health areas like hypertension, high blood pressure, diabetes, and weight loss due to its antimicrobial and antioxidant effect [74]. Its anticancer and antiviral properties are well known. Consumption of Spirulina can bring balanced metabolism of cholesterol by levels of HDL increasing, which in turn result in healthy cardiovascular function. Spirulina actually helps to develop immunity by enhancing phagocytic activity in macrophages and by generating antigen-specific antibodies in people with depression and hyperactivity disorder with attention deficit. Spirulina, along with conventional supplementation of iron-folic when used to tackle nutritional anaemia in remote tribal population of India, show improvements [76]. In terms of production, the market of Spirulina is dominated by companies like Watershed Wellness Centre, Bio-Alternatives, Valley Naturals, Springtime Inc and Puritan's Pride. The Spirulina powder costs about 1000 rupees per kg. It is a prokaryotic multicellular filamentous cyanobacterium and consists of mainly two genera Spirulina and Arthrospira [77]. Species of Spirulina have been reported from Goalpara district Assam [20]. Directorate of Biotechnology, Government of Tripura, initiated mass cultivation of Arthrospira platensis in combination with open mass cultivation in Tripura. The Micro Small Medium Enterprises (MSME) Development Institute offered training programme on "Spirulina cultivation" which constitute an algae introduction, innovative international and national marketing, harvest and post-harvest technology, Spirulina culture and production and Spirulina functions. Moreover, the Ministry of MSME has set up one national-level entrepreneurship development institute in Guwahati Assam.

\section{Ankistrodesmus sp}

In Kajiranga National park, Assam [78], Ankistrodesmus septatus Oettli reported from Ribhoi district, of Meghalaya. Ankistrodesmus falcatus (Corda) Ralfsa freshwater oleaginous microalgae were grown in batch culture, and the media constituents influence, calorific value (CV), total lipid (TL) content, nitrogen sources and $\mathrm{pH}$ on growth $(\mu)$ was compared [79]. Ankistrodesmus falcatus growth was tested in various concentrations of sodium chloride $(0.04 \mathrm{M}$ to $0.34 \mathrm{M}$ ), and results reveal the highest growth as well as lipid content at $0.17 \mathrm{M} \mathrm{NaCl}$ concentration [80].

\section{Botryococcus sp}

In Chandrapur locality of Kamrup district, Assam, the strain Botryococcus braunii (GUBIOTJTBB1) was isolated from the collected water samples of a freshwater reservoir. One strain is isolated from Loktak lake Manipur, and the effect of various nutrient stress condition on biofuel production was investigated [32].

\section{Scenedesmus}

The maximum growth showed by Scenedesmus strain in $\mathrm{CO}_{2}$ gas at $4758 \mathrm{mg} / \mathrm{l}(103.8 \mathrm{mg} / \mathrm{l}$ for seven days) and bicarbonate at $45 \mathrm{ppm}$ (30.9 $\mathrm{mg} / \mathrm{l} /$ day for $17 \mathrm{~d}$ ). Two potent indigenous microalgae strain Scenedesmus quadricauda and Scenedesmus dimorphus isolated from Assam and studied for $\mathrm{CO}_{2}$ mitigation and biomass production [19]. It has also been isolated from Kaziranga National Park (KNP) Assam [78]. Another high temperature and $\mathrm{CO}_{2}$ Scenedesmus obliquus SA1 strain was isolated from Assam, India and studied for $\mathrm{CO}_{2}$ sequestration efficiency [81]

\section{Future prospects}

Compounds from microalgal extracts have accepted as having greater biological and economic importance than dried biomass. In the sense of global population growth and availability of terrestrial food items, microalgae may provide sustainable and reliable replacements for widely used commodities of animal or plant origin. To date, however, only a limited number of strains have been utilised in the nutritional and pharmaceutical purposes. Major research and development would entail the transition from a niche market to the widespread use of algal products as food commodities. In turn, this will include improving existing strains through genetic engineering, and modifications or screening new species to the growth of microalgae with increased targeted metabolite production. 

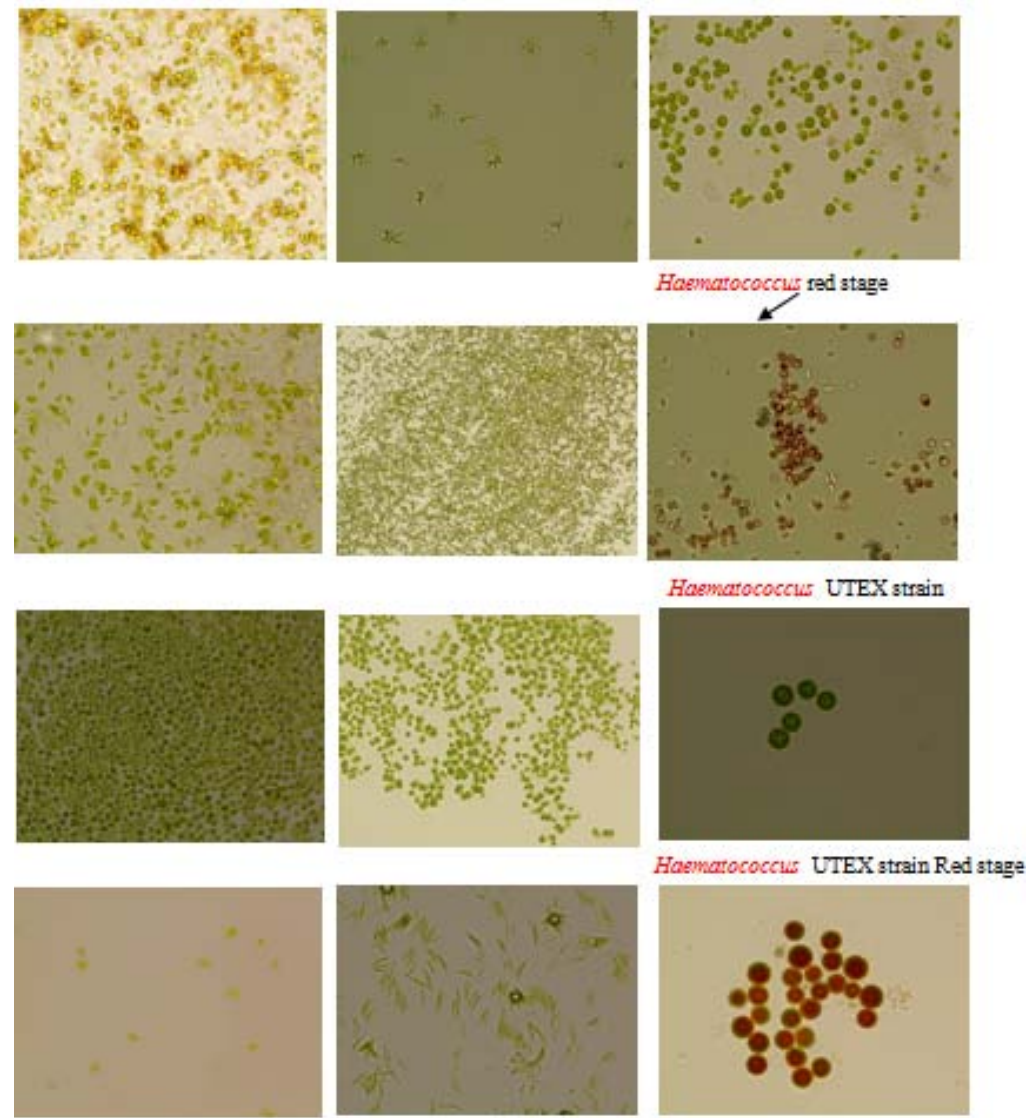

Fig. 6: Strains isolated from different water bodies of Assam, India [30, 78]

\section{CONCLUSION}

Northeast India provides plentiful opportunities to explore the biodiversity at its habitat. There is evidence that there are some algae which already came into an endangered list and the day is not far that many will become extinct without being discovered. It is the peak time to address big questions regarding the conservation of algae and attempt to bring together expertise for the same. Evidence also report that algae have small means of survival that must be accounted into account in the context of biogeography. It is now a big matter of concern to apply possible tactics and methods necessary to achieve realistic protection, including culture collections potential use and application of legislation for in situ conservation.

In Northeast India, the concept of Nutraceutical is still at in the stage of infancy. Despite having rich algae resources in Northeast India, the commercialisation of value-added products are still at infancy. For a successful economy from value-added products from algae resource, the processes should be optimised as following 1 . Identification and preservation, 2. Cost-efficient large-scale cultivation with quality 3 . Efficient harvesting, 4 . Commercialisation. However, this demands awareness training as well as skilled infrastructure development. Different institutes including Gauhati University, IIT Guwahati, Tezpur University Institute of Bioresources and sustainable development, Imphal are working on the varied perspective of algae. Strategies including co-cultivation, start-up pilot projects, the opening of nutraceutical Food Park would stride up to translate these studies from a laboratory to mass commercialisation. It will further pave the way to not only the herbbased but also algae-based nutraceuticals market from North East India. Therefore, we should join hands together to develop new ways and move on with the idea "think outside the box" that will in return be a wow factor for achieving a prosperous economy of our region that is North East India.

\section{FUNDING}

Nil

\section{AUTHORS CONTRIBUTIONS}

All the authors have contributed equally.

\section{CONFLICT OF INTERESTS}

Declared none

\section{REFERENCES}

1. Nilesh Hemantkumar J, Ilza Rahimbhai M. Microalgae and its use in nutraceuticals and food supplements. In: Microalgae from physiology to application. IntechOpen; 2020.

2. Veluchamy C, Palaniswamy R. A review on marine algae and its applications. Asian J Pharm Clin Res 2020;13:21-7.

3. Bhattacharjee M. Pharmaceutically valuable bioactive compounds of algae. Asian J Pharm Clin Res 2016;9:43-7.

4. Rayapu L, Makkar F, Chakraborty K, Valluru L. Phytochemical evaluation and antimicrobial activity of gracilaria opuntia: an important anti-diabetic red marine macroalgae. Int J Curr Pharm Res 2017;9:37.

5. Varfolomeev SD, Wasserman LA. Microalgae as source of biofuel, food, fodder, and medicines. Appl Biochem Microbiol Springer 2011;47:789-807.

6. Brown EM, Allsopp PJ, Magee PJ, Gill CIR, Nitecki S, Strain CR, et al. Seaweed and human health. Nutr Rev Oxford University Press Oxford, UK 2014;72:205-16.

7. Yaakob Z, Ali E, Zainal A, Mohamad M, Takriff MS. An overview: biomolecules from microalgae for animal feed and aquaculture. J Biol Res Springer 2014;21:6.

8. Jena M, Adhikary SP. Chlorococcales (Chlorophyceae) of eastern and north-eastern states of India. Algae Inchon Citeseer 2007;22:167. 
9. Baruah P, Kakati B. Water quality and phytoplankton diversity of gopeswar temple freshwater pond in Assam (India). Bangladesh J Bot 2013;41:181-5.

10. Sharma H, Das D, Sarmah P, Rout J. A study on freshwater algal communities of pond ecosystems from southern Assam. Vegetos 2019;32:19-32.

11. Ghosh A, Sarkar S, Gayen K, Bhowmick TK. Effects of carbon, nitrogen, and phosphorus supplements on growth and biochemical composition of Podohedriella sp. (MCC44) isolated from northeast India. Environ Prog Sustain Energy 2020;12:39.

12. Muthuraj M, Selvaraj B, Palabhanvi B, Kumar V, Das D. Enhanced lipid content in Chlorella sp. FC2 IITG via high energy irradiation mutagenesis. Korean J Chem Eng 2019;36:63-70.

13. Garcia JL, Vicente M de, Galan B. Microalgae, old sustainable food and fashion nutraceuticals. Microb Biotechnol 2017;10:1017-24.

14. Wadmare N, Roy S, Kociolek JP, Karthick B. Two new aerophilic species of Stauroneis Ehrenberg (Bacillariophyta) from the Eastern Himalayas. Bot Lett Taylor Francis 2019;166:234-45.

15. Lahan JP, Kalita R, Bora SS, Barooah M. Screening of potential oleaginous microalgae from dhemaji district of Assam, India. Int J Agric Environ Biotechnol New Delhi Publishers 2012;5:141-4.

16. Lahan JP, Kalita R, Bora SS, Deka A, Boro RC, Barooah M. Isolation and identification of algae from dhemaji district of Assam, India. Trends Biosci 2012;5:220-1.

17. Jena M, Adhikary SP. Chlorococcales (Chlorophyceae) of Eastern and North-eastern States of India. ALGAE 2007;22:167-83.

18. Devgoswami CR, Kalita MC, Talukdar J, Bora R, Sharma P. Studies on the growth behavior of Chlorella, Haematococcus and Scenedesmus sp. in culture media with different concentrations of sodium bicarbonate and carbon dioxide gas. African J Biotechnol Academic Journals (Kenya) 2011;10:13128-38.

19. Goswami RCD, Kalita MC. Scenedesmus dimorphus and Scenedesmus quadricauda: two potent indigenous microalgae strains for biomass production and $\mathrm{CO}_{2}$ mitigation a study on their growth behavior and lipid productivity under different concentration of urea as nitrogen source. J Algal Biomass Util 2011;2:2-4.

20. Deka SJ, Sarma GC. Preliminary checklist of oscillatoriaceae (Cyanophyta), Goalpara District, Assam, India. Int J Appl Biol Pharm Technol 2011;2:430-3.

21. Oinam G, Singh OA, Tiwari ON. Part II: an account of heterocystous nostocalean cyanobacterial biodiversity of Manipur, India. J Indian Bot Soc Indian Botanical Society 2011;90:45-59.

22. Devi TI, Tiwari ON. Exploration of oscillatorialean cyanobacteria of manipur, india, falling under indo-burma biodiversity hotspots. J Indian Bot Soc Indian Botanical Society 2011;90:33-44

23. Maibam RS, Gupta A. Nutrient content in fresh water red algae (Lemaneaceae, Rhodophyta) from rivers of Manipur, north-east India. Electron J Environ Agric Food Chem 2011;10:2262-71.

24. Basu S, Roy AS, Mohanty K, Ghoshal AK. Enhanced $\mathrm{CO}_{2}$ sequestration by a novel microalga: Scenedesmus obliquus SA1 isolated from bio-diversity hotspot region of Assam, India. Bioresour Technol 2013;14:3369-77.

25. Kumar V, Muthuraj M, Palabhanvi B, Ghoshal AK, Das D. High cell density lipid rich cultivation of a novel microalgal isolate Chlorella sorokiniana FC6 IITG in a single-stage fed-batch mode under mixotrophic condition. Bioresour Technol 2014;170:115-24.

26. Yasmin F, Buragohain BB, Sarma R. Aquatic Algae from Kaziranga National Park, Assam, India. Int J Curr Microbiol Appl Sci 2015;4:297-302.

27. Bora A, Gogoi HK, Veer V. Algal Wealth of Northeast India. In: Bioprospecting of Indigenous Bioresources of North-East India. Singapore: Springer Singapore; 2016. p. 215-28.

28. Thajamanbi M, Rout J, Thajuddin N. Blue green algae from rice fields of Karimganj district, Assam, North East India. Life 2016;50:23.
29. Ghosh A, Khanra S, Mondal M, Devi TI, Halder G, Tiwari ON, et al. Biochemical characterization of microalgae collected from north east region of India advancing towards the algae-based commercial production. Asia Pacific J Chem Eng 2017;12:745-54.

30. Sehgal A, Goswami K, Pal M, Chikkaputtaiah C, Chetia P, Boruah HPD. Morpho-taxonomic, genetic, and biochemical characterization of freshwater microalgae as potential biodiesel feedstock. 3 Biotech 2019;9:137.

31. Das B, Deka S. A cost-effective and environmentally sustainable process for phycoremediation of oil field formation water for its safe disposal and reuse. Sci Rep 2019;9:15232.

32. Manchanda T, Tyagi R, Sharma DK. Application of nutrient stress conditions for hydrocarbon and oil production by Botryococcus braunii. Biofuels Taylor Francis 2019;10:271-7.

33. Sarkar S, Manna MS, Bhowmick TK, Gayen K. Extraction of chlorophylls and carotenoids from dry and wet biomass of isolated Chlorella thermophila: Optimization of process parameters and modelling by artificial neural network. Process Biochem 2020;96:58-72.

34. Dixit A, Kumar N, Kumar S, Trigun V. Antimicrobial resistance: progress in the decade since emergence of New Delhi metallo-lactamase in India. Indian J Community Med Publ Indian Assoc Prev Soc Med Wolters Kluwer 2019;44:4.

35. Astarita G, Langridge J. An emerging role for metabolomics in nutrition science. Lifestyle Genomics Karger Publishers 2013;6:181-200

36. Baruah PP, Baruah R, Das P. A preliminary study on diversity and distribution of Spirulina, Arthrospira and Glaucospira (Cyanobacteria) in the Brahmaputra Valley of Assam (India). Feddes Repert Wiley Online Library 2014;125:85-92.

37. Bishop WM, Zubeck HM. Evaluation of microalgae for use as nutraceuticals and nutritional supplements. J Nutr Food Sci 2012;2:1-6.

38. Huang C, Zhang Z, Cui W. Marine-derived natural compounds for the treatment of Parkinson's disease. Mar Drugs Multidisciplinary Digital Publishing Institute 2019;17:221.

39. Bhattacharjee M. Pharmaceutically valuable bioactive compounds of algae. Asian J Pharm Clin Res 2016;9:43.

40. Mathur M. Bioactive molecules of Spirulina: a food supplement. Bioact Mol Food Ref Ser Phytochem Springer, Cham; 2018.

41. Andrade LM, Andrade CJ, Dias M, Nascimento CAO, Mendes MA. Chlorella and Spirulina microalgae as sources of functional foods. Nutraceuticals Food Suppl 2018;6:45-58.

42. Sanzo G Di, Mehariya S, Martino M, Larocca V, Casella P, Chianese $\mathrm{S}$, et al. Supercritical carbon dioxide extraction of astaxanthin, lutein, and fatty acids from Haematococcus pluvialis microalgae. Mar Drugs Multidisciplinary Digital Publishing Institute 2018;16:334.

43. Ishaq AG, Matias Peralta HM, Basri H. Bioactive compounds from green microalga-Scenedesmus and its potential applications: a brief review. Pertanika J Trop Agric Sci 2016;39:1-16.

44. Ambati RR, Gogisetty D, Aswathnarayana Gokare R, Ravi S, Bikkina PN, Su Y, et al. Botryococcus as an alternative source of carotenoids and its possible applications an overview. Crit Rev Biotechnol Taylor Francis 2018;38:541-58.

45. Jerez Martel I, Garcia Poza S, Rodriguez Martel G, Rico M, Afonso Olivares C, Gómez Pinchetti JL. Phenolic profile and antioxidant activity of crude extracts from microalgae and cyanobacteria strains. J Food Qual 2017;201:71-8.

46. Richmond A, Hu Q. Handbook of microalgal culture: applied phycology and biotechnology. John Wiley and Sons; 2013.

47. Reyna Martinez R, Gomez Flores R, Lopez Chuken U, Quintanilla Licea R, Caballero Hernandez D, Rodreguez Padilla C, et al. Antitumor activity of Chlorella sorokiniana and Scenedesmus sp. microalgae native of nuevo leon State, Mexico. Peer J Peer J Inc; 2018. p. 6e4358.

48. Ryu NH, Lim Y, Park JE, Kim J, Kim JY, Kwon SW, et al. Impact of daily Chlorella consumption on serum lipid and carotenoid profiles in mildly hypercholesterolemic adults: a doubleblinded, randomized, placebo-controlled study. Nutr J Springer 2014;13:57. 
49. Medina Jaritz NB, Carmona Ugalde LF, Lopez Cedillo JC, Leon F SLR De. Antibacterial activity of methanolic extracts from Dunaliella salina and Chlorella vulgaris. Wiley Online Library; 2013.

50. Kitada K, Machmudah S, Sasaki M, Goto M, Nakashima Y, Kumamoto S, et al. Antioxidant and antibacterial activity of nutraceutical compounds from Chlorella vulgaris extracted in hydrothermal condition. Sep Sci Technol Taylor Francis 2009;44:1228-39.

51. Takyar MBT, Khajavi SH, Safari R. Evaluation of antioxidant properties of Chlorella vulgaris and Spirulina platensis and their application in order to extend the shelf life of rainbow trout (Oncorhynchus mykiss) fillets during refrigerated storage. LWT Elsevier 2019;100:244-9.

52. Samarakoon KW, Ko JY, Shah MMR, Lee JH, Kang MC, Kwon ON, et al. In vitro studies of anti-inflammatory and anticancer activities of organic solvent extracts from cultured marine microalgae. Algae Korean Soc Phycol 2013;28:111-9.

53. Sansawa H, Takahashi M, Tsuchikura S, Endo H. Effect of Chlorella and its fractions on blood pressure, cerebral stroke lesions, and life-span in stroke-prone spontaneously hypertensive rats. J Nutr Sci Vitaminol (Tokyo) Center for Academic Publications Japan 2006;52:457-66.

54. Kwak JH, Baek SH, Woo Y, Han JK, Kim BG, Kim OY, et al. Beneficial immunostimulatory effect of short-term Chlorella supplementation: enhancement of natural killercell activity and early inflammatory response (Randomized, double-blinded, placebo-controlled trial). Nutr J Springer 2012;11:53.

55. Merchant RE, Carmack CA, Wise CM. Nutritional supplementation with Chlorella pyrenoidosa for patients with fibromyalgia syndrome: a pilot study. Phyther Res Wiley Online Library 2000;14:167-73.

56. Merchant RE, Andre CA. A review of recent clinical trials of the nutritional supplement Chlorella pyrenoidosa in the treatment of fibromyalgia, hypertension, and ulcerative colitis. Altern Ther Health Med Innovision Communications 101 Columbia, Aliso Viejo, CA 92656 USA 2001;7:79-92.

57. Ghosh A, Khanra S, Mondal M, Devi TI, Halder G, Tiwari ON, et al. Biochemical characterization of microalgae collected from north east region of India advancing towards the algae based commercial production. Asia Pacific J Chem Eng Wiley Online Library 2017;12:745-54.

58. Kumar V, Muthuraj M, Palabhanvi B, Ghoshal AK, Das D. High cell density lipid rich cultivation of a novel microalgal isolate Chlorella sorokiniana FC6 IITG in a single-stage fed-batch mode under mixotrophic condition. Bioresour Technol Elsevier 2014;170:115-24.

59. Muthuraj M, Kumar V, Palabhanvi B, Das D. Evaluation of indigenous microalgal isolate Chlorella sp. FC2 IITG as a cell factory for biodiesel production and scale up in outdoor conditions. J Ind Microbiol Biotechnol Springer 2014;41:499511.

60. Kumar V, Muthuraj M, Palabhanvi B, Das D. Synchronized growth and neutral lipid accumulation in Chlorella sorokiniana FC6 IITG under continuous mode of operation. Bioresour Technol Elsevier 2016;200:770-9.

61. Palabhanvi B, Muthuraj M, Kumar V, Mukherjee M, Ahlawat S, Das D. Continuous cultivation of lipid rich microalga Chlorella sp. FC2 IITG for improved biodiesel productivity via control variable optimization and substrate driven $\mathrm{pH}$ control. Bioresour Technol Elsevier 2017;224:481-9.

62. Sarkar S, Manna MS, Bhowmick TK, Gayen K. Extraction of chlorophylls and carotenoids from dry and wet biomass of isolated Chlorella thermophila: Optimization of process parameters and modelling by artificial neural network. Process Biochem Elsevier; 2020.

63. Cotas J, Leandro A, Pacheco D, Gonçalves AMM, Pereira L. A comprehensive review of the nutraceutical and therapeutic applications of red seaweeds (Rhodophyta). Life 2020;10:19.

64. Fassett RG, Coombes JS. Astaxanthin in cardiovascular health and disease. Molecules Molecular Diversity Preservation International 2012;17:2030-48.

65. Guerin M, Huntley ME, Olaizola M. Haematococcus astaxanthin: applications for human health and nutrition. TRENDS Biotechnol Elsevier 2003;21:210-6.

66. Dhankhar J, Kadian SS, Sharma A. Astaxanthin: a potential carotenoid. Int J Pharm Sci Res Citeseer 2012;3:1246.

67. Fakhri S, Yosifova Aneva I, Farzaei MH, Sobarzo Sanchez E. The neuroprotective effects of astaxanthin: therapeutic targets and clinical perspective. Molecules Multidisciplinary Digital Publishing Institute 2019;24:2640.

68. Uchiyama K, Naito Y, Hasegawa G, Nakamura N, Takahashi J, Yoshikawa T. Astaxanthin protects-cells against glucose toxicity in diabetic db/db mice. Redox Rep Taylor Francis 2002;7:290-3.

69. Gurumayum S, Senapati SS. Exploration of algal varieties from panikhaiti area of guwahati using winogradsky column. Int J Curr Microbiol Appl Sci 2017;6:1195-204.

70. Ramanujam P, Siangbood H. Diversity of algal communities in Umiew River, Meghalaya. Indian Hydrobiol 2009;12:65-73.

71. Devi LB, Rout J. Diversity of soil algae from vegetable crop fields of Cachar district, Assam, India. Indian J Ecol Indian Ecological Society 2018;45:689-96.

72. M Bishop W, M Zubeck H. Evaluation of microalgae for use as nutraceuticals and nutritional supplements. J Nutr Food Sci 2012;2:5.

73. Singh S, Marskolay S. Spirulina as an alternative solution to food security: an extensive review on clinical studies. J Crit Rev 2020;7:3411-31.

74. Nihal B, Gupta NV, Gowda DV MM. Formulation and development of topical anti acne formulation of Spirulina extract. Int J Appl Pharm 2018;10:229.

75. Capelli B, Cysewski GR. Potential health benefits of spirulina microalgae. Nutrafoods Springer 2010;9:19-26.

76. De M, Halder A, Chakraborty T, Das U, Paul S, De A, et al. Incidence of anemia and effect of nutritional supplementation on women in rural and tribal populations of eastern and northeastern India. Hematol Taylor Francis 2011;16:190-2.

77. Ahsan M, Habib B, Parvin M, Huntington TC, Hasan MR. A review on culture, production and use of spirulina as food for humans and feeds for domestic animals. FAO Fish Aquac Circ FAO; 2008.

78. Yasmin F, Buragohain BB, Sarma R. Aquatic Algae from Kaziranga National Park, Assam, India. Int J Curr Microbiol Appl Sci 2015;4:297-302.

79. Talukdar J. Influences of dissolved inorganic carbon and nitrogen sources on growth, total lipid content and calorific value of freshwater oleaginous microalga Ankistrodesmus falcatus (Corda) ralfs. Environ Res Eng Manag 2012;61:14-25.

80. Kalita N, Baruah G, Goswami RCD, Talukdar J, Kalita MC. Ankistrodesmus falcatus: a promising candidate for lipid production, its biochemical analysis and strategies to enhance lipid productivity. J Microbiol Biotechnol Res 2011;1:148-57.

81. Basu S, Roy AS, Mohanty $\mathrm{K}$, Ghoshal AK. Enhanced $\mathrm{CO}_{2}$ sequestration by a novel microalga: Scenedesmus obliquus SA1 isolated from bio-diversity hotspot region of Assam, India. Bioresour Technol Elsevier 2013;143:369-77. 